\title{
De titaantjes van Tachtig: De Poëtische Spectator van Jacobus Bellamy en de zijnen (1784-1786)
}

\author{
J.J. KLOEK
}

Jongens waren het, maar aardige jongens - de studenten die in de vroege jaren tachtig van de achttiende eeuw vanuit Utrecht probeerden de vaderlandse literatuur nieuw leven in te blazen. $Z i j$ waren lid van het literaire genootschap ‘Dulces Ante Omnia Musae' maar vormden daarbinnen een eigen clubje dat lak had aan alle genootschappelijk formalisme. Ze kozen dan ook geen officiële naam maar duidden zich niet zonder zelfspot aan als 'de keurelingen' of 'de genialische vrienden'. Het waren jongens als Jacobus Bellamy, Jan Hinlópen, Jan Pieter Kleyn, Willem Anthony Ockerse, Adrianus Uyttenhooven, Willem Carp en Sebald Fulco Rau. Wat hen bond was de vriendschap en de literatuur. Ze waren bekend met wat het buitenland voortbracht en dweepten met de humor van Laurence Sterne, met de luchtige lofzangen op de liefde en de wijn van de zogenaamde anacreontici in Duitsland en ook - in het serieuze - met de verheven oden van Klopstock. In hun denken over poëzie was hun grote leidsman Edward Young, die in zijn Conjectures on Original Composition (1759) de dichters had opgeroepen allereerst zichzelf te zijn en niet hun heil te zoeken in het navolgen van grote voorbeelden. Intussen waren ze er ook van overtuigd dat de dichterlijke creativiteit moest worden geleid door studie van het wezen van schoonheid en literatuur, dus door esthetische theorie. Van een sentimentele cultus van het gevoel moesten ze niets hebben, evenmin als van de in hun ogen schoolmeesterachtige poëziekritiek zoals die in de traditionele dichtgenootschappen werd bedreven. Ze hebben zich een bescheiden plaats veroverd in de geschiedenis van de Nederlandse literatuur - bescheiden, want het algemene oordeel is toch wel dat hun ambities veel hoger 


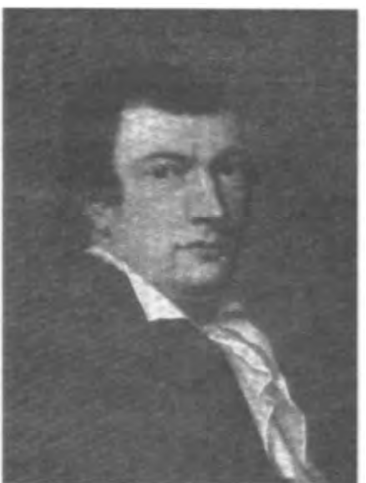

Jacobus Bellamy

reikten dan wat ze als dichters zelf waarmaakten. Titaantjes inderdaad. ${ }^{1}$

Het hart van de groep was Jacobus Bellamy (1757-1786). Niet alleen werd hij door de anderen als de meest getalenteerde onder hen beschouwd, hij moet ook een charismatische persoonlijkheid zijn geweest. Hij nam iedereen voor zich in en nog 36 jaar na zijn dood werd hij geëerd met een literaire Gedenkzuil. ${ }^{2}$

Het was ook Bellamy die het initiatief nam om de nieuwe opvattingen institutioneel uit te dragen door middel van een tijdschrift voor literaire theorie en kritiek. Zo'n tijdschrift - in de literatuurgeschiedschrijving is daar eigenlijk nooit op gewezen - was op dat moment iets nieuws. Bladen als de Vaderlandsche Letteroefeningen bestreken de hele culturele productie, de eigenlijke literatuur vormde slechts een bescheiden onderdeel. Bovendien had de Letteroefeningen geen eigen literair programma, het blad wilde veeleer voorlichten dan opiniëren. De recensies waren over het algemeen dan ook vlak en voor zover er oordelen werden gegeven, sloten die aan bij traditionele literaire opvattingen. De Poètische Spectator, zoals Bellamy zijn blad doopte, schuwde de polemiek niet en evenmin de filerende analyse. 'Wij moeten beter recenseeren als eenige recenseur in de maandschriften', zo hield medewerker Uyttenhooven zichzelf voor. Zo zien we hier voor het eerst in de geschiedenis van de Nederlandse letterkunde een literaire groep haar opwachting maken met wat voortaan het visitekaartje bij uitstek zou worden: een eigen programmatisch tijdschrift. Ze manifesteerden zich zelfs met twee tijdschriften, want voor hun poëzie en literaire proza richtte in dezelfde tijd Willem Ockerse met medewerking van Bellamy de Proeven voor het verstand, de smaak en het hart op. ${ }^{3}$

De groep hield zich wel, zoals tot ver in de negentiende eeuw het gebruik zou blijven, achter haar bladen verscholen. Noch de titelpagina 
van de Proeven noch die van de Spectator vermelden een naam. In beide tijdschriften zijn de bijdragen ongesigneerd of getekend met ondoorzichrige initialen.

Deze discretie van de vroegere tijdschriftredacties stelt de latere onderzoeker vaak voor problemen, zeker wanneer er ook geen archivalia zijn nagelaten. ${ }^{4}$ De Vaderlandsche Letteroefeningen bijvoorbeeld gunt ons nauwelijks een blik achter de schermen; we weten niet wie deel uitmaakten van de kring van medewerkers, laat staan welke namen aan individuele bijdragen moeten worden verbonden en hoe ze tot stand kwamen. De communicatie tussen redacteuren en medewerkers blijft een gesloten boek. De interne geschiedenis van De Poëtische Spectator daarentegen is tot op grote hoogte te reconstrueren. Dat is te danken aan het feit dat Bellamy al direct na zijn vroege dood een legende werd, waardoor relatief veel van zijn brieven bewaard zijn gebleven. In deze correspondentie, en met name in Bellamy's brieven aan de in Amsterdam (gelukkig voor ons niet in Utrecht!) gevestigde uitgever van De Poëtische Spectator, Antony Mens, zien we het tijdschrift moeizaam geboren worden en nog moeizamer het tweede nummer bereiken, waarmee het meteen de laatste adem uitblaast. ${ }^{5}$

$\mathrm{Al}$ in november 1782 had Mens aan Bellamy, die hij een half jaar eerder had leren kennen, de suggestie gedaan om iets literair-kritisch te schrijven, dat hijzelf dan zou uitgeven. Hiervan kwam voorlopig niets, evenmin als van andere gezamenlijke ondernemingen, ${ }^{6}$ maar de twee werden al gauw goede vrienden en schreven elkaar geregeld. Waarschijnlijk heeft Bellamy pas voor het cerst met Mens over zijn tijdschriftplannen gesproken op woensdag 21 april 1784, nadat hij 'met de schuit van eene' in Amsterdam was aangekomen. ${ }^{7}$ Mens hapt onmiddellijk toe: nog voor de grote vakantie zal het eerste nummer in 6 vel ( 96 pagina's) verschijnen. Bellamy zet zich aan een inleiding, en heeft het stuk al voor half mei voltooid. 'Zoo ik mij niet bedrieg zijn er zeer goede dingen in', schrijft hij vol zelfvertrouwen aan Mens. ${ }^{8}$ Een paar dagen later krijgt Mens de kopij, met al meteen gedetailleerde aanwijzingen voor de opmaak: 
Hier nevens mijn inleiding! Die moet je maar eens heel goed zijn! Begin maar te zetten. [...] De tytel is hier ook bij - op de linkerzijde moet dat latijnsche motto staan. 9 - De eerste pagina moet halfweg dat is: net in de midden beginnen. - dit begrijptje? Ik zou aan den voet der bladzijden maar geen custos $^{10}$ zetten. wat doen die dingen daar? - niet meer dan ons wagtschip voor Lillo! ${ }^{11}$ Met een mooije letter hoor! - De regels niet te eng! Anders komt er te veel op een bladzijde - en de koopers moeten het toch betaalen! - op goed papier! hoor! [...]

Proeven moet ik hebben, dit spreekt van zelf! - Nu! Die zult ge mij ook gaarne geven. [...]

NB! Nog iets - eens en vooral - anders valt 'er in de proeven te veel te doen - alles moet niet met een y maar met ij gedrukt worden - met een dubbelde ij niet met een grieksche $y$ !

Bravo! Neem dit toch in acht - en prent het den drukker diep in zijn conscientie. ${ }^{12}$

De inleiding, getiteld 'Aan de lezer', is een programma. ${ }^{13}$ Met een beroep op natuur en waarheid wordt hardhandig afgerekend met het pseudogevoel van de sentimentelen en de rijmelcultuur in de genootschappen. Wat ons land mist, zijn geen dichters maar deskundige beoordelaars die welbeargumenteerd het kaf van het koren weten te scheiden. In die leemte wil het tijdschrift voorzien.

De afkeer van formalistische regels komt niet alleen tot uiting in de spot met de beuzelachtige genootschapskritiek, die zich vooral bezig zou houden met taalkundige details. ${ }^{14}$ In de inleiding wordt tevens gekozen voor het voorlopige 'fragment' boven de afgeronde verhandeling en bij voorbaat verwerpt de redactie het juk van de periodiciteit: op een verschijningsfrequentie wil zij zich niet vastleggen. Wanneer we dus De Poëtische Spectator (en hetzelfde geldt voor de Proeven) een tijdschrift noemen, moeten we wel een voorbehoud maken.

De redactie werd volgens de titelpagina gevoerd 'door eenige vaderlandlievende vrienden'. De bent die hiermee wordt aangeduid, 
bestond, zo onthult de correspondentie, in eerste instantie verder uit de al genoemde Adrianus Uyttenhooven (1759-1839) en de met Bellamy bevriende patriottenvoorman Pieter Quint Ondaatje (1758-1818). Uyttenhooven, die sinds zijn afstuderen vanuit het ouderlijk huis te Naarden uitkeek naar een vacante predikantsplaats, kan al op 14 mei een bijdrage aan Bellamy sturen. Erg tevreden is hij er zelf niet over:

Zie daar zestien bladzijden geknoei. Laat ze bij u eens de revue passeeren. [...] Mijn geschrijf bevalt mij niet zo goed het kon, ik heb een zekere luim van geluk (zo als wij het noemen) [nodig(?)] die ik deze week onder mijn bereik niet heb kunnen krijgen, dan zou het beter gegaan hebben. ${ }^{15}$

De betreffende 'zestien bladzijden geknoei' bevatten een nogal voorspelbaar satirisch portret van 'de recensent'. Overigens zegt hij Bellamy toe binnen een week enkele poëziebesprekingen te zullen leveren.

Intussen kan Bellamy enthousiast aan Mens melden dat hij nog een nieuwe 'medearbeider' heeft opgedaan en wel een man van 'ongemeen veel genie', die 'verrukt' is over de plannen en dadelijk een stuk heeft toegezegd 'over de agterlijkheid van onze dichters'. ${ }^{16}$ Het is de al een paar jaar afgestudeerde Jan Hinlópen (1759-1808), inmiddels tot lid van de Utrechtse vroedschap verkozen maar nog steeds een van de meest actieve 'genialische vrienden'. Dat hij Orangist is terwijl Bellamy en Ondaatje openlijk de Patriottenbeweging zijn toegedaan, schijnt in het minst geen belemmering te vormen.

$\mathrm{Na}$ deze vliegende start stagneert de voortgang. Op 18 mei vraagt Uyttenhooven een week uitstel voor zijn recensies: hij moet een proefpreek houden. ${ }^{17}$ Ondaatje schijnt te hebben afgehaakt - de politiek zal hem meer hebben beziggehouden. 'Waar blijft Ondaatje?', schrijft Uyttenhooven begin juni, en dat is het laatste wat we over hem vernemen. ${ }^{18}$ In dezelfde brief verzoekt Uyttenhooven opnieuw om respijt. Voor de vakantie zal het wel niet lukken, dus Bellamy en Hinlópen moeten samen het eerste nummer maar vullen. Maar Hinlópen heeft 
klaarblijkelijk moeite met zijn aangekondigde provocatie: we horen er niets over. Intussen wordt Mens ongeduldig: hij wil voor de zomer in ieder geval twee van de zes vellen drukken en heeft daarvoor nog onvoldoende kopij. Inderhaast - 'ik heb dit zoo maar eens gaauw geknoeit' - schrijft Bellamy dan een kritisch stuk 'Is het uitschrijven van prijsvragen nuttig voor de Dichtkunst?', geïnspireerd door een aankondiging in de Leidsche Courant van de voor dat jaar door het genootschap 'Kunst Wordt door Arbeid Verkreegen' gevraagde prijsverzen. De teneur van het stuk laat zich raden.

Het gaat overigens niet goed met Bellamy. Ondanks zijn robuuste fysiek kwakkelt hij met zijn gezondheid. Bovendien is zijn geliefde Francina Baane in het verre Vlissingen niet alleen geografisch onbereikbaar: haar moeder, die weinig vertrouwen heeft in de soliditeit van de pretendent, heeft iedere omgang verboden. In een bui van neerslachtigheid vertrouwt hij zijn vriend Jan Pieter Kleyn toe: 'Kleyn! Ik ga sterven. $\mathrm{Ik}$ leef geene twee jaren meer. Ik voel den dood reeds door mijne aderen woelen'. ${ }^{19}$ Kleyn zelf lacht het leven op dat moment toe: hij heeft het jawoord verkregen van Antoinette, het zusje van Ockerse. Maar dit bericht is weer verpletterend geweest voor Uyttenhooven, die ook op Antoinette verliefd was en dacht zich van haar wedermin verzekerd te mogen weten. Zwaarmoedig stelt hij zich een toekomst voor van dorpsdominee zonder vrienden en met een meid voor het huishouden. In deze brief van 18 juni 1784 bezweert hij Bellamy echter ook dat hij nu echt aan de slag gaat: 'Ik beloof $U$ heilig ik zal aan het werk gaan in de andere week - ik zal het aan Mens zenden: gij kunt er staat op maken.'20 Volgt een langdurig stilzwijgen. Maar Bellamy, die de vakantie bij zijn moeder in Vlissingen doorbrengt, zit hem niet achter de vodden. Hij heeft inmiddels wel wat anders te doen. Francina's moeder staat hem nu toe althans over de vloer te komen! Als hij Mens in cen brief verslag uitbrengt, roert hij de Spectator slechts kort en luchtigjes aan:

Heeft J.... [Janus Uyttenhooven] u nog niets gezonden? Het kan er immers niet door? Schrijf eens aan hem, dat ik een gruwelijke Satyre op hem maaken zal, zoo hij niet schielijker werkt. ${ }^{21}$ 
Er volgt voor Bellamy een dichterlijk productieve periode, met onder meer een lijkdicht op de pas overleden revolutionair Johan Derk van der Capellen, een ode op zijn vriend Hinlópen en - allicht - een gedicht dat zijn geluk met 'Fillis', Francina, bezingt. Aan zijn tijdschrift lijkt hij nauwelijks te denken. Pas eind september maant hij Uyttenhooven weer. Deze schrijft een lange, deemoedige brief terug: behalve nog steeds door proefpreken wordt hij nu ook gekweld door misgivings over het predikantschap. Maar het echte probleem lijkt toch vooral te zijn geweest dat Uyttenhooven lamgeslagen was door faalangst. Kon hij de pretenties van het blad wel waarmaken?

Tk wil van het onderwerp juist niet afgaan als ik u zeg: dat ik geen theoretische kennis genoeg bezit om goed te Recenseeren; - wij moeten Recenseeren [...] en wij moeten beter recenseeren als eenige recenseur in de maandschriften, dit is nog al zo iet. [...] Of anders zal onzen Spectator, vergelijk de voorreden en de recensent, een miserabel figuur maken. ${ }^{22}$

Toch ziet hij een maand later, op 30 oktober, kans de in mei gedane belofte in te lossen, met een bespreking van de bundel Mengeldichten van het genootschap 'Volmaakter door den tijd'. Hij heeft gekozen voor de fluwelen handschoen, schrijft hij Bellamy:

Schrijft mij eens hoe het $\mathrm{u}$ bevallen is; ik heb de historie nog al civil, daar ik kon, getrakteerd; als wij te veel kammen krijgen wij geen crediet genoeg: liever tusschen beide in het eerst iets dat nog al tamelijk is, een weinigje prijzen. ${ }^{23}$

Het stuk moet Bellamy bitter zijn tegengevallen. Het spoort hem wel aan zelf nog maar een kritiek te schrijven. In 'niet veel meer tijd dan een dag' produceert hij een hardhandige, gedetailleerd analyserende recensie van de bundel Gezangen van Martinus Nieuwenhuyzen, die 22 pagina's zou beslaan. ${ }^{24}$ Wat hij met Uyttenhoovens bijdrage zal doen weet hij nog niet, maar Mens kan weer aan de slag: 
Indien de Drukker van den Spectator nog leeft - indien de letter nog niet gesleten is - Indien de afgedrukte bladen nog onbeschadigd zijn bewaard gebleven - vlieg dan schielijk naar den Drukker - en bezorg hem deze copij!

Van J. heb ik ten minsten papier genoeg ontvangen - maar wat ik er van zal gebruiken - weet ik niet. daar is geen kiesheid hoegenaamd in. - nu! hiervan nader! ${ }^{25}$

Uiteindelijk zal hij niets van het stuk plaatsen. Uyttenhooven - zo zal blijken - krijgt geen enkele reactie. Mens, blij dat er nu vaart in zit, stuurt bijna per ommegaande de proef terug. Half in ernst zegt hij voortaan alleen nog maar kopij van Bellamy zelf te willen ontvangen. En waarom is zo'n veelbelovend schrijver voor de kansel bestemd?

Gij ziet dat de Drukker nog in Leven is, de Letter noch heel, en de afgedrukte bladen is gelukkig nog geen worm in - dezen proef wacht ik cito terug, met noch eenige Nieuwe Copy van de hand van J. Bellami. ' $t$ Is zo, gij moet dit stukje alleen afwerken, ik wilde het gaarne tot 6 vel brengen, en tegen December of in ' $t$ begin van die maand uitgeeven: dus moet er spoed gemaakt worden. - Waarom is uw bestemming niet om in dit vak alleen te werken? Waarom moet gij Domenee worden? Nuttelooze Vraagen! Mogelijk zult gij ook noch eens als Predicant uitmunte, gelijk gij waarlijk in de Fraaye lettere uitmunt, zo ik eenigtsints mijn Eige Gevoel en oordeel vertrouwen kan. $^{26}$

Tntussen was er niets terechtgekomen van Hinlópens voornemen de 'agterlijkheid van onze dichters' in het licht te stellen en ook verder had hij nog steeds geen bijdrage geleverd. Maar waarschijnlijk is het nieuwe stuk dat Bellamy omstreeks 20 november aan Mens stuurt, 'Ter gedagtenisse van $\mathrm{H}$. Dullaart', van zijn hand. ${ }^{27}$ Het ingetogen opstel wil de 100 jaar eerder gestorven dichter Heiman Dullaert aan de vergetelheid ontrukken - een heel wat minder brisante onderneming dan de oor- 
spronkelijk aangekondigde! Een armoedebod lijkt ook dat, waarschijnlijk door toedoen van Bellamy, ${ }^{28}$ het nog geen 6 pagina's tellende betoog is opgeblazen tot 21 door de integrale opname van Dullaerts 'Uitbreiding van koning Davids civde harpgezang'. Maar Bellamy heeft er duidelijk weer zin in:

Dit vaers moet op een nieuwe bladzijde beginnen - en maar één couplet, op de eerste bladzijde - en vervolgens op de volgende bladzijden twee coupletten - niet cursijf maar - zoo een letter als het origineel. - wij zullen dan zien hoe het uitkomt - het vaers zal, geloof ik 15 bldz. beslaan. - lees eens, op pagina 9: uw oppervorstelijke hand $E c$.

He! Dat is schoon! - maar kleine lui kent men niet.

Zult ge het nu zoo, volgens mijn hoogDichterlijk bevel, laaten uitvoeren - en mij schielijk een proef bezorgen?29

Op dit moment waren bijna vijf van de zes geplande vellen gevuld. Maar dan gebeurt er iets dat Bellamy tot snelle actie noopt. In het najaar van 1784 verschijnt namelijk de eerste bundel van een reeks essays over esthetica en poëtica van Rhijnvis Feith, de Brieven over verscheiden ondenwerpen. Bij de 'genialische vrienden' slaan ze in als een bom.

Wat is namelijk het geval? In de eerste helft van oktober van dat jaar was op een van de bijeenkomsten van de 'genialische vrienden' gesproken over een nieuw dichtgenre dat Europa veroverde maar in Nederland nog niet was beoefend: de romance. Bellamy en Rau besloten er beiden hun krachten aan te wagen en de Proeven voor het verstand, de smaak en her hart, waarvan het tweede nummer in november zou uitkomen, de Nederlandse primeur ervan te laten hebben. En zo dichtte Rau zijn 'Ewald en Elize' en Bellamy zijn 'Roosje'. Maar terwijl de Proeven nog op de pers lagen, zagen Feiths Brieven het licht en tot ontsteltenis van de vrienden bevatten die een opstel 'Over de Romanze', met daarin opgenomen twee romances van Feith zelf. Weg primeur! Het enige wat Bellamy nog kon doen was in een op de valreep aangebracht naschrift er met gelukwensen 
aan Feith op te wijzen dat 'Roosje' strikt genomen geen romance was omdat het niet in de middeleeuwen speelde. Zo was de eer van oorspronkelijkheid gered.

Maar er was nu ook haast geboden met de Spectator. Ofschoon hij het nergens expliciet zegt, zal Bellamy met gemengde gevoelens hebben geconstateerd dat Feith in de opstellen 'Raad aan eenen jongen Dichter', 'Over het onnatuurlyke, geoutreerde, onwaarschijnlijke' en 'Over de Navolging der Natuur, en der schoone Natuur' esthetische opvattingen verdedigt die niet erg ver aflagen van zijn eigen credo 'losheid, waarheid, natuur'. Hun verschillende waardering van het sentimentele was in wezen een kwestie van gradatic en niet van principe. Maar dat was wel het laatste wat de ambitieuze Bellamy zou willen erkennen: hij zou eens voor een epigoon van de 'sentimentele armee' kunnen worden aangezien! De uitgave van de Spectator, met zijn kritische uitvallen naar sentimenteel gezucht, kon geen moment meer wachten - dan maar vijf blad (vel) groot. Aan Mens, met een mix van ergernis en zelfspot:

\section{Amicissime!}

Ik dagt dat de drukker dood was! - doch hij leeft!

En praat gij van nog een blad? - al kon de Spectator morgen uitkomen, het zou des te beter zijn! Hebt gij dan de brieven van Feit [sic] niet gezien? Gij zijt een slegt generaal! Neen! de Spectator moet ten eersten in de waereld! - iedere dag verzuim, is schade voor mijn eer! Begrijpt gij dit niet? zie - zal de sentimenteele armee zeggen - naauwlijks begint onze Ritmeester met zijn volk uittekomen, of men komt ook - men geeft, in navolging van onzen ritmeester, dezelfde monteering \&c. \&c. - en is dit te dulden? De spectator moet ten eersten op marsch! - bij den tweeden veldtocht zal ik zorgen, dat de armee grooter is!

Dat de Ritmeester mij dit zoo afgewonnen

Heeft!....'t Kan er niet door!

En onder zijn ligte troepen zijn romanzen

Ook!....'t Schreeuwt! 
Bij Sanctus Apollo! Maak dat de spectator schielijk uitkome! [...] - Nu rijd den drukker toch schoon na! [...]

Die Ritmeester! ${ }^{30}$

Er volgt dan een hectische periode van proeven die over en weer gaan: 'ik moet volstrekt nog een revisie hebben - Dat Latijn is bedroefd! - Die letters op den tytel moeten geheel anders zijn!' - enzovoorts.

Intussen heeft Uyttenhooven nog altijd niets gehoord over het lot van zijn recensie. Ook Mens, bij wie hij langs is geweest, heeft hem begrijpelijk - niet wijzer gemaakt. Gekrenkt schrijft hij Bellamy:

Hoe is het, bevalt het u niet? - dan zeg het ronduit maar weiger niet te schrijven. Zend het mij wederom. Ik zal het overschrijven, naarzien etc: kan het in het geheel niet geplaatst worden, zend het mij te rug, en ik zal niets meer zenden. - [...]

Geloof echter, niet tegenstaande gij thans aan het draaijen zijt; dat ik zonder ophouden ben

Uwe Uyttenhooven ${ }^{31}$

Toe Bellamy heeft gereageerd is jammer genoeg niet overgeleverd; in ieder geval raakte de relatie niet blijvend beschadigd. Als het aan Hinlópen had gelegen, was trouwens ook nog Uyttenhoovens andere bijdrage, 'De recensent' gesneuveld. Maar het lag niet aan Hinlópen: die wist van niets. Bellamy, warm in zijn vriendschappen, had als redacteur autocratische trekjes en zelfs Hinlópen, met wie hij in Utrecht toch frequent contact onderhield, heeft de kopij voor de Spectator nooit onder ogen gehad. Dit blijkt uit een brief van hem aan Bellamy van 28 december 1784 , als - zes maanden na de oorspronkelijke planning - het eerste nummer van het blad verschenen is:

Uwe inleiding bevalt mij zeer wel: maar de Recensent zeer slegt. Hoe komt gij in het derde stukje, in den derden regel aan heeft geweest. In het Iv ben ik meest [met] u eens; eene reflexie: op p. 53, weet gij wel 
dat die geheel veelzeggende wending: God der Goden, vergeef toch den aanstaanden dooden zijn zonden, en zijne zegepraal bijna woordelijk is overgenomen uit Klopstock? ${ }^{32}$

Daarna komt bijna twee maanden lang de Spectator niet ter sprake in de correspondentie. Maar in de tweede helft van februari $1785 \mathrm{krijgt}$ Mens een voor het tijdschrift bestemde bijdrage toegestuurd van iemand die zich niet bekendmaakt. Hij stuurt haar door naar Bellamy, die de verrassing van zijn leven heeft:

$7 \mathrm{k}$ giste naar alle mogelijke dichters die mij konden kennen, doch, ik kon niet begrijpen wie hij wezen zou; de hand scheen mij ook niet alleen niet onbekend, maar zelfs zeer kennelijk te zijn. Ik liet het schrift aan twee vrienden zien; op het eerste gezigt zeiden zij Eenstemmig: wat denkt gij? van Alphen!

Ja vriend! Het is van Alphen! Grooter satisfactie kon ik met mijnen spectator nooit verkregen hebben; het streelt mijne eigenliefde zeer. De andere heeren zullen nu ook meer werken; want die eer moet voor mij alleen niet blijven. ${ }^{33}$

Bellamy's opgetogenheid had een bijzondere reden. Allereerst had hij grote bewondering voor Hiëronymus van Alphen, aan wiens literairesthetische opstellen hij veel verschuldigd was. Juist deze schatplichtigheid evenwel had hem eind 1783 tot een 'vadermoord' gebracht. In een hoogst onberaden, anoniem gepubliceerde Brief aan den Heere en Mr. H. van Alphen had hij deze dichterlijk plagiaat van hemzelf aangewreven. Van Alphen had niet geantwoord maar was natuurlijk not amused geweest. Hij koesterde echter ook geen wrok, zo bleek nu. Hij complimenteert de redactie met haar werk en biedt ter plaatsing aan een niet onkritische maar over het geheel genomen welwillende bespreking van de poezie in het eerste deeltje van de Proeven voor het verstand, den smaak en het hart. Hij geeft dus aan, de jongeren serieus te nemen. Intussen speelt hij het spel van de anonimiteit consequent: hij verraadt zichzelf 
niet en wendt voor de Spectator-redacteur niet te kennen, en ook niet te weten dat deze dezelfde is als de auteur van een paar in zijn recensie zeer geprezen gedichten. Tegelijk laten enkele subtiele plaagstoorjes geen ruimte voor twijfel: hij wist drommels goed met wie hij te doen had en het ging dus om een welbewuste handreiking. Bellamy speelt het spel mee; op de omslag van de brief aan Mens maant hij deze discreet te zijn: 'Wie dien brief geschreven heeft weet ik niet - Dit begrijpt gij wel?'34

Bellamy hoopte dat 'de andere heeren' door Van Alphens stuk tot 'meer werken' zouden zijn geïnspireerd maar de eerste die weer iets aflevert, is hijzelf. Al op 6 maart heeft hij niet alleen een hoffelijk dankwoord 'Aan den schrijver van den voorgaanden brief gereed waarin hij op hoffelijke toon zijn literaire opvattingen nog eens toelicht, maar ook een bespreking van de kort tevoren verschenen luimige Proeven van slaapdichten van O.C.F. Hoffham. ${ }^{35}$ Kort daarop meldt hij aan Francina:

Van den Spectator zegt men vrij algemeen, dat ik de schrijver ben.

Doch het raakt mij niets - zoo ik iets tot verbetering kan toebrengen, zal het genoeg zijn. ${ }^{36}$

Daarna eisen andere zaken zijn aandacht op. Zijn nieuwe bundel Gezangen ligt bij Mens op de pers, alsmede een herdruk van de vaderlandsche Gezangen. Het levert de gebruikelijke hectiek op. In het kader van zijn opleiding moet hij zijn eerste preken houden. Hij wordt lid van de pas opgerichte 'Maatschappij tot Nut van 't Algemeen' en geeft op verzoek van secretaris Nieuwenhuyzen - dezelfde die hij in de Spectator stevig had aangepakt - zijn oordeel over enkele aan het genootschap toegezonden gezangen. Maandenlang lijkt de Spectator uit zijn gedachten te zijn. Begin oktober pas - er zijn sinds het vorige nummer negen maanden verstreken - schrijft hij Mens er weer over, als hij de bespreking heeft voltooid van de tiende bundel Proeven van Poëtische Mengelstoffen van het genootschap 'Kunstliefde Spaart Geen Vlijt' (weinig poëzie, veel rijmelarij) en begonnen is aan een stuk over Loosjes' heldendicht M.A. de Ruyter $(1785) \cdot{ }^{37}$ 
Mens kan dan beginnen met drukken. In november is er een wat geprikkelde correspondentie over de drukproeven die veel te lang op zich laten wachten en waarin, als ze er eenmaal zijn, nota bene de brief van Van Alphen blijkt te ontbreken. Revisieproeven dus weer. Bovendien wordt Bellamy voortdurend door koorts geplaagd. Maar hij heeft nog allerlei recensieplannen: van het bundeltje Zeeuwsche Dichtgedachten (1785), door enkele provinciegenoten uitgebracht, en van het debuut Mijne minderjaarige zangster, waarvan de onverhulde erotiek tot opschudding had geleid. De anonieme minnezanger was de zeventienjarige Johannes Kinker, een bekende van Bellamy uit 'Dulces'.

Die minderjaarige zangster zal ik in den Spectator ook iets zeggen; de schrijver weet dat ik den Spectator schrijf, en ik heb hem gezegd, dat hij een veegtje hebben zou. ${ }^{38}$

Beide bijdragen zijn ongeschreven gebleven. Wel stuurt hij kort daarop Mens een uitgebreide bespreking van Voor Capellen tot den Pol, een bundel prijsverzen op de het jaar tevoren overleden revolutionaire voorman. Op goedgehumeurde toon wordt alle holle retoriek doorgeprikt. Maar Mens krijgt op z'n duvel:

Gij zijt een schoon kaerel! Gij zoudt mij boeken voor den Spectator zenden; ja! niets, dat er naar gelijkt! Wanneer zal ik die ontvangen? [...] mijn Capellen hebt gij mij ook niet gezonden - 't kan er niet door! ${ }^{39}$

Mens moet het stuk onmiddellijk gedrukt hebben, want al op zondag 13 oktober stuurt Bellamy de gecorrigeerde proef terug naar Amsterdam. En legt meteen de zweep er weer over:

Dezen krijgt ge franco! ja! Man! Laat het werk toch wat spoedig voord gaan. Ziet deze proef nog eens na, of ge geen fouten meer ziet. [...] Hebt ge die Zeeuwsche dichtgedagten reeds?40 
Over bijdragen van anderen wordt nooit gesproken. Nergens blijkt dat Hinlópen iets in de pen heeft. De eindelijk te Simonshaven beroepen Uyttenhooven meldt slechts dat het hoofd hem omloopt en dat hij nog steeds treurt om zijn Antoinette - over de Spectator geen woord. Er is een brief overgeleverd van 26 oktober 1785 waarin een anonieme letterkundige vriendenkring haar medewerking aanbiedt, onder bijvoeging van een in het gezelschap gehouden redevoering. Het heeft tot niets geleid. ${ }^{41}$

De hele maand november is Bellamy ziek, met koorts en pijn. Begin december gaat het iets beter maar nu verwijt hij Mens dat die de zaken laat sloffen. Wanneer komen nu eindelijk eens de definitieve proeven van de al voltooide stukken? 'Misschien hebt gij wel geen genegenheid, om den Spectator voordtezetten, doch, dit zoudt gij mij wel op een andere wijs te kennen kunnen geven.' 42 In zijn antwoord ontkent Mens dit ten stelligste. Hij gooit het erop dat de drukker de benodigde letter in gebruik heeft en bovendien, zo aan het eind van het jaar, overladen is met werk. Impliciet geeft hij echter te kennen dat de Spectator ook bij hemzelf niet de hoogste prioriteit heeft:

daar zal nu van dit jaar niets van komen - ik denk dat het' $t$ voorjaar also goed is; daar koomt in dezen tijd te veel uit. De attentie van het Leezend Publiek valt dan zo veel niet op een werk dat noch zo veel als nieuw is. ${ }^{43}$

Dit betekent een uitstel van enkele maanden, terwijl er al een jaar verlopen is sinds de vorige aflevering. Maar bij Bellamy lijkt het elan eruit te zijn. Voor zijn doen opmerkelijk lauw antwoordt hij dat hij wel doorhad dat het meer aan Mens zelf dan aan de drukker lag: 'Baas! Ik begrijp dit stuk wel!'44

Half december vertrekt Bellamy met kerstvakantie naar Vlissingen. Eind januari is hij terug in Utrecht, ziek alweer. Op 1 februari brengt hij een bezoek aan Mens, die hij had gevraagd enkele recent verschenen titels klaar te leggen, misschien met het oog op mogelijke bespreking in de Spectator. ${ }^{45} \mathrm{Hij}$ voelt zich dan ' gansch niet wel', wordt geteisterd door 
hoest en reumatische pijnen. Het zou het laatste contact tussen de redacteur en zijn uitgever zijn. Daarna gaat het snel bergafwaarts. Willem Carp houdt Mens op de hoogte. Hij is 'ziek, zeer ziek', heet het op 24 februari, 'gansch niet beter' op 4 maart, 'zeer slegt' de dag daarop. Carp zal ook wel Bellamy's overlijden op 11 maart hebben gemeld. Hij en Hinlópen zaten aan het sterfbed.

Het zijn niet Uyttenhooven of Hinlópen maar het is Mens die na Bellamy's dood het initiatief neemt om het tweede deel van De Poëtische Spectator te bezorgen. Op 13 april vraagt hij aan Bellamy's moeder of er zich nog stukjes onder de nagelaten papieren bevinden. Daarvoor, zo krijgt hij ten antwoord, moet hij bij de beheerder daarvan zijn: Hinlópen. Intussen heeft hij Uyttenhooven verzocht de intussen gereed gekomen drukproeven na te kijken. Uit diens 'door het een en ander belet' vertraagde antwoord blijkt dat Mens en hij daarnaast graag een bundel nagelaten poëzie van Bellamy zouden willen uitgeven. Maar hoe staat Hinlópen daar tegenover, die, volgens Uyttenhooven, zelf 'er zich waarschijnlijk een feest van zal maken om ze uit te geven'? Vandaar dat Uyttenhooven zich voorstelt om een stuk te schrijven dat afhankelijk van Hinlópens plannen kan functioneren als voortede bij het tweede Spectator-deeltje of bij de bundel nagelaten gedichten. Hij wil Hinlópen daarover peilen, Mens moet dus even geduld hebben. ${ }^{46}$

Of er overleg met Hinlópen is geweest weten we niet; nagelaten gedichten van Bellamy zagen noch in een aparte bundel noch in de Spectator het licht maar werden later in herdrukken van zijn werk opgenomen. Het tweede nummer van de Spectator zou nog tot oktober 1786 op zich laten wachten. Behalve de bijdragen die Bellamy al aan Mens had gestuurd bevat het enkel het toegezegde stuk van Uyttenhooven, waar deze naar alle waarschijnlijkheid dus weer lang tegenaan heeft gehikt. Het is een niet als in-maar als uitleiding fungerende 'Brief aan mijne vriendin C.M.B...., ,7 waarin het karakter van Bellamy wordt geschetst en zijn eer wordt verdedigd tegen geruchten over een loszinnige levenswandel. Aan de betekenis van de overledene als 


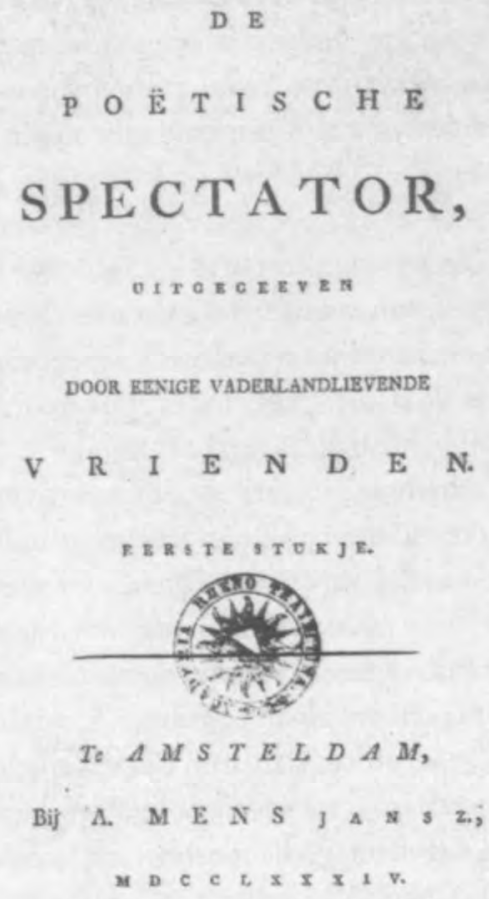

criticus en recensent wijdt Uyttenhooven geen woord en aan de toekomst van de Spectator welgeteld één zin, die nauwelijks vrijblijvender kon: 'het wordt der goedwilligheid en patriötisme overgelaten zijn begonnen werk te vervolgen'. Dat voorspelde weinig goeds. En inderdaad, een bedankbriefje van Francina Baane aan Mens voor de toezending van het tweede deeltje, ${ }^{48}$ is het laatste stuk dat geboekt kan worden in het dossier De Poëtische Spectator. 
Dat De Poëtische Spectator weinig meer heeft kunnen zijn dan een incident in de geschiedenis van de Nederlandse literatuur en van het Nederlandse tijdschrift, was in de eerste plaats natuurlijk een gevolg van de dood van Bellamy. Het is echter de vraag of het heel anders zou zijn gelopen als hem een langer leven beschoren was geweest. Busken Huet oppert onder het nodige voorbehoud dat Bellamy had kunnen uitgroeien niet alleen tot 'een van onze oorspronkelijkste en klassickste dichters' maar tegelijk tot 'redakteur van een solide letterkundig tijdschrift'. ${ }^{49}$

Zou het denkbaar zijn, dat 'solide tijdschrift'? Bij het overzien van de levensloop van De Poëtische Spectator dringt toch eerder een tegengestelde gedachte zich op. Bellamy moest de last van het blad nagenoeg in zijn eentje dragen, maar eigenlijk wilde hij ook niet anders. Zijn medewerkers brachten weinig in maar hadden ook weinig in te brengen. Zou hij iemand met veel literair talent en ambitie naast zich hebben geduld? Afgaand op de correspondentie was Bellamy in ieder geval niet iemand die zijn medewerkers opdreef en nog minder een alerte talent scout. Als verzamel- en kweekplaats van artistiek talent kan De Poëtische Spectator evenmin als de flankerende Proeven voor het verstand, den smaak en het hart, ook maar in de schaduw staan van De Gids vijftig jaar later, laat staan van De Nieuwe Gids na weet een halve eeuw. Het verwerpen van een verplichtende periodiciteit leidde bovendien, zoals we zagen, tot een weinig solide vrijblijvendheid die het uitgroeien van de groep tot een 'beweging' bepaald niet bevorderde. En dan: er lokten perspectieven buiten de literatuur. Verscheidene van de titaantjes zouden het nog ver brengen. Hinlópen bijvoorbeeld tot staatsraad, Ockerse tot voorzitter van de Nationale Vergadering. En Uyttenhooven? Die schopte het tot predikant te Brouwershaven, waar hij zich verdienstelijk maakte door het doen oprichten van een standbeeld voor de dichter Jacob Cats. 